\title{
Protecting the Interests of the Indigent Tenant: Two Approaches
}

\author{
Carl Schier*
}

$\mathrm{T}^{\mathrm{m}}$ HE PERSON WITH INADEQUATE MEANS, seeking a suitable family dwelling in the city, is often a hapless figure. Space can be had only on a short-term basis, and most available housing is run-down, dirty, and without adequate services. ${ }^{1}$ Furthermore, if the community is progressive and in the throes of redevelopment, one never knows when the neighborhood will be slated for wholesale destruction. ${ }^{2}$ Hence, many poor families are little better than transients within the metropolis, resettling periodically in one blighted area or another. ${ }^{3}$

For some, public housing fills the need for shelter. It is secure from condemnation by the local planning authority and adequate in the sense that it is warm and dry and provides more creature comforts than private fare. ${ }^{4}$ It is also scarce. ${ }^{5}$ A great need exists for additional units, and many of the yearly contracts must be placed in an eligible "pool" until units are vacated. ${ }^{6}$ But even though the demand is high; the poor do not bike

* B.A., 1959, Lehigh University; LL.B., 1963, University of Michigan. Assistant Director for Research, Urban Law Program, University of Detroit School of Law. For a discussion of the Urban Law Program at the University of Detroit, see Miller \& Daggitt, The Urban Lazv Program of the University of Detroit School of Law, this symposium.

1 In 1960, 12.4\% of all of Detroit's housing, or 63,635 units, were either deteriorating or dilapidated. 2 U.S. Bureat of THE Census, Dep't of Comaderce, Census of Housng: 1960, pt. 3, at 57-59 (1963). For a general description of the manner in which the poor are housed, see Agee \& Evans, Let Us Now Praise famous Men (1960) ; Max, The Wasted Americans 123-30 (1964).

2 In Detroit's Gratiot project, for example, 129 acres were cleared, during a ten-year period, to bare earth, requiring relocation of 1,958 families and 989 single persons, who had been living in 1,550 dwelling units. Detroit Housing Cosan's, Gratrox Redeveloparent Project, Fladal Report 6 (1964). See generally Anderson, The Federai Bulcdozer 52-70 (1964).

3 5,530 families and single persons were uprooted in Detroit's ten redevelopment projects. Detrort Housing Concu'n, QuARTERLy REPort, Fourth QUARTER 15 (1964). There is no way of knowing how many families moved from the seven projects that were formerly residential in character, only to find they had relocated in a proposed redevelopment area, but interviews indicate many families moved twice, and others expect to move again.

4 The Detroit Housing Commission leaflet advertises: "All dwellings have range and refrigerator-All units have private bath and ample closet space in addition to living room, kitchen, bedrooms and parking facilities." Detroit Housing Comn'n, Modern Housing with Reasonable Rent, 1963.

5 For example, the 1960 census report showed Detroit with 78,437 units that needed or would soon need replacing or repair, 2 U.S. BUREAU of THE CENSUS, op. cit. supra note 1. Available public housing now totals 8,113 units, and no new units have heen built since 1960 . Detroir Housing Comar's, op. cit. stipra note 3, at 12 .

${ }^{6}$ In Detroit, as of December 31, 1965, 790 families waited in the eligible pool. Dexrorr Housns Cosar's, op. cil. supra note 3 , at 14. 
projects. Living in one adds to the burden of being poor because it strips away disguise and pretense and identifies poverty by address. ${ }^{7}$ Raising families there is difficult, higl-rise buildings provide no place to play, and the stark, sterile surroundings are more confinement than home to the children. ${ }^{8}$ Such places have become, in many instances, dormitories housing refugees from the war against poverty.

For these reasons, one may assume that large numbers of poor families will be relying on private accommodations for the foreseeable future.

Since the cost of outright ownership is prohibitive, and since the market could not supply a sufficient number of single family dwellings in the event the means to purchase magically appeared at hand, the poor will rent, and the party to whom they must look to meet their loousing needs will be the private landlord.

It would seem that adequate lousing for the indigent tenant would depend on the fulfillment of the following conditions: (1) adequate space at reasonable cost; (2) a term of sufficiently long duration to ensure a degree of permanency; (3) maintenance of the leased premises and common areas in a habitable state, or at least a condition that meets housing code requirements, at the time of letting and througlout the term; (4) provision of basic services, such as heat, light, and water; and (5) an assurance of privacy. The urgent question is whether the law provides a means to meet these conditions.

Public law provides a limited resource for the attorney seeking relief for lis clients. Where the perplexing question is how to find adequate space at a price the tenant can afford, the long term remedy will lie only in the public law sector. Housing is in short supply, and the demand is higl. In addition, the market is distorted by considerations of race and poverty; hence the asking price reflects considerations which have nothing to do with the quality of the interest transferred. Although it is beyond the scope of this article to explore the problem in great detail, it would seem that the enactment of fair lousing legislation, ${ }^{9}$ and the appropriation of funds to construct additional public housing should have a meliorating effect on the total market.

Maintenance of leased premises and of common areas, adequacy of

7 Persons interviewed in two Detroit projects were unhappy about living there. They revealed that police will not answer calls, doctors will not venture in, and merchants, upon learning of the address, will not extend credit.

8 In the Detroit projects, private police, popularly called rent-a-cops, patrol all buildings; all grass plots are encircled by heavy chains, and even the advertising leaflet for the projects shows father and sons playing baseball in the parking lot, as there are no playgrounds.

0 By 1964, eighteen states and thirty-four cities had enacted some form of fair housing laws. Weaver, Foreword to U.S. Housing and Home Finance Agenct, Fam Hgusing Laws 3 (1964). 
facilities for supplying utilities, and to some extent, privacy, are all the province of housing codes, whose enforcement and the problems attendant thereon have been exhaustively treated elsewhere. ${ }^{10}$

Duration, perhaps one of the most important considerations of the indigent tenant, is not subject to public regulation, except in one jurisdiction presently enforcing rent control legislation. ${ }^{11}$

Although some writers have expressed concern that the private law of landlord and tenant is not sufficiently developed to adequately protect the tenant, ${ }^{12}$ at least one article discusses a number of remedies that should dispel some of these concerns. ${ }^{13}$

The specific private law problem is low to balance adequately the rights of landlord and tenant and to provide the impoverished tenant with rights of action which will make secure the interests set forth above. in the remaining pages an attempt will be made to outline two private law approaches for protecting further the righits of indigent tenants, the first through the courts, and the second in the legislature.

To achieve progress in the courts two case-law developments should prove useful. One development gives rise to a theory for imposing affirmative obligations on the landlord by implication, and the second involves the assimilation of a modified contract doctrine of substantial performance; applicable to the performance of both express and implied promises in the lease, replacing the liarsh doctrine that covenants in a lease are independent. Although the opinions on which these developments are based are Michigan decisions, a brief perusal of cases noted in several of the standard treatises indicate that the analysis would hold in other jurisdictions as well. ${ }^{14}$ Whether or not a particular court would accept such an approach on a case of first impression is another matter.

The legislative approach involves the enactment of a statutory lease which defines the minimum leasehold estate of the tenant, and balances the respective rights of both landlord and tenant.

${ }^{10}$ See, e.g., Note, The Enforcement of Municipal Housing Codes, 78 HARv. L. REv. 801 (1965).

11 N.Y. UNCONSOL. LAws $\$$ 8581-97 (McKinney Supp. 1965).

12 E.g., LeBlanc, Landlord-Tenant Problems, in Conference Proceedings, The Extensrons of Legal Services To The Poor 51 (U.S. Dep't of H.E.W. 1964); Lesar, Landlord and Tenant Reform, 35 N.Y.U.L. REv. 1279 (1960).

${ }^{13}$ Schoshinski, Remedies of the Indigent Tenant: Proposal For Change, 54 Gro. L.J. 519 (1966).

14 See 6 WuTISTON, Contracts $\$ \S 890,890 \mathrm{~A}$ (3d ed. 1957) for a general contract approach to the interpretation of leases; 1 ANCERICAN LAW of ProperTy \$ 3.45, at 267-68 nn.2, 7-12 (Casner ed. 1952), for illustrative cases on implied covenants. Compare 3A CoRBriv, CoNTRACrs $\$ 686(1960)$, where the theories of constructive eviction in leases and constructive conditions in other contracts are related. 
I

TWO CASE-LAW DEVELOPMENTS IN THE TENANTS' FAVOR

\section{A. Affirmative Obligations Imposed on the Landlord by Implication}

As a general matter, parties to a contract establish reciprócal rights and duties through the accepted medium of arm's length bargaining. Thus, in the ideal circumstance, where the parties meet on equal terms to establish their obhgations under the agreement, the prospective landlord offers the premises and certain services, and the prospective tenant offers to pay a price felt to be in accord with the going rate. When all terms have been agreed to by both sides, the exchange is concluded and the parties consider themselves bound. Of course, ideal circumstances are foreign to the poor tenant. He doesn't bargain with his landlord, for he cannot meet the landlord on anything approximating equal terms. Without bargaining strength he must accept the landlord's offer as to duration, price, and services. Yet it may be possible to create by implication obligations affecting the nature and quality of the tenant's interest.

From what sources will such duties stem? At least two can be clearly identified. The first source is the intent of the parties as it is manifest in the terms of the agreement and the circumstances surrounding its formation. It derives from the consensual nature of the arrangement and sounds in contract. The second source is the relationship which exists between the parties, in this case the relationship of landlord and tenant. Althougl the relationship is created by virtue of the parties' consent, its characterization as a source of duty is apart from its contractual foundations and sounds more in warranty. ${ }^{15}$

From the language of the contract one may infer that the parties mintended more than they actually expressed. The limits of intent can be expanded by implication. One such expansion, based on a contractual analysis, is that the landlord intended and therefore impliedly promised that the premises would be fit for the purposes which the parties revealed in the agreement. In Tyler $v$. Disbrow, ${ }^{16}$ the defendant had leased a dwelling louse from plaintiff; covenanting that she had "received said demised premises in good order and condition,"17 and that she would yield them up in as good condition. The defendant also promised to "keep said premises in a clean and healthy condition." 18

15 For a discussion of the history of warranty, and its origins in tort, see Prosser, TORTS 651-57 (3d ed. 1964); Prosser, The Implied Warranty of Merchantable Quality, 27 MINN. L. REv. 117, 118-25 (1942).

1640 Mich. 415 (1879).

17 Id. at 417.

18 Ibid. 
Defendant took possession of the house, found that its sewers were not adequate to carry off waste, that refuse collected, and that the house was filled with "foul smells and stench."19 Defendant tried unsuccessfully to remedy the defects and then attempted a surrender, which the plaintiff refused.

On appeal, a judgment for defendant in a suit for rent was affirmed, the court stating that it was "manifest from these [defendant's] covenants that the condition of the premises was a distinct consideration," that "when the landlord rents his house with a distinct understanding that it is in good condition, that: becomes a part of the consideration."21 That the court had not conceived of the landlord's duty as arising from an express covenant was clear, for the court added that "the effect of the assertion could not be stronger if the covenant had been made by the lessor instead of the lessee."22

Here, the theory of the duty is pure contract, and the successful defense is predicated on a breach of a contractual duty.

The landlord-tenant relationship itself may give rise to obligations binding on the landlord, irrespective of the parties' failure to indicate any intent. The duty is conceived much like the duty in a negligence situation, but it is expressed in terms that sound in warranty. In Leonard v. Armstrong, ${ }^{23}$ the defendant leased a house from plaintiff, and when it proved totally unfit for habitation for reasons running the gamut from openings in the walls to sewage in the basement, it was held on appeal that such conditions, stemming from defects in the construction of the house; rendered the premises untenantable and unfit for habitation, and hence the tenant was not compelled to remain on the premises and pay rent. ${ }^{24}$ The issue was himited to the condition of the premises at the time the tenant took possession, and the court was satisfied that evidence had been permitted on that point only. It was held to be the duty of the landlord to put the premises in proper condition, a duty which the court appeared to assume existed as a natural concomitant of the relationship.

The court stated that the tenant "rented the premises for a dwelling for his family, believing as it appears, that the premises were tenantable and fit for the purposes for which he rented them. ${ }^{325}$ It is suggested that the court was not requiring as an element of the defense that the tenant show rehance on some statement or other representation of the lessor

\footnotetext{
19 Id. at 416.

20 Id. at 417.

21 Ibid.

22 Ibid.

2373 Mich. 577, 41 N.W. 695 (1889).

$24 I d$. at 581,41 N.W. at 696.

25 Ibid. (Emphasis added.)
} 
as would be the case in an action for fraud. Here the "reliance" required would appear to be nothing more than the general dependence of one party upon another when a particular relationship has been created. In the instant case, the lessor knew of the proposed use, since he rented the premises as a dwelling. The lessor was in a better position to know of the defects and to either repair or warn of their presence, whether he actually knew or not. The existence of the legally recognized relationship of landlord and tenant, and the factors of knowledge, control, and dependency which color that relationship, give rise to the particular consequence in which we are interested, the existence of an implied covenant of fitness for the purpose intended. ${ }^{26}$

The policy supporting impled obligations stems from the need to recognize affirmative duties, imposed on one party for the benefit of the other, which arise out of the nature of the relationship and the fact that one party must depend or rely on the other's superior knowledge, control, or abibity to absorb certain risks. ${ }^{27}$

\section{B. Limitations}

\section{Reliance on Contract Theory}

The point being urged is that the sources of implied affirmative obligations in leasehold transactions are two: the parties' intent as manifest from the language and circumstances, and the existing landlord-tenant relationship. A failure to distinguish adequately between these two sources led to the confusion of theory and a denial of rehef in the early English law.

In the second half of the 19th century implied covenants of fitness were not recognized. The reason was as stated by Baron Parke in Hart $v$. Windsor, ${ }^{28}$ where he denied the defense of breach of implied covenant in a suit for rent where tenants liad to vacate a dwelling house because of an infestation of bugs.

The principles of the common law do not warrant such a position [that a lease contains an implied contract of fitness] and though, in the case of a dwelling house for habitation, there is no apparent injustice in inferring a contract of this nature, the same rule must apply to land taken for other purposes-for building upon, or for cultivation, and there would be no limit to the inconvenience which would ensue. ${ }^{29}$

26 For another rationale for imposing implied obligations, see 3 CoRBIn, ConTracts $\S 592$ (1960 ed.), where the burden of a risk unanticipated by the contract is imposed on one party by implication.

27 But cf. Pines v. Perssion, 14 Wis. 2d 590, 111 N.W.2d 409 (1961), for the statement of a different policy, more specifically directed to providing adequate lousing than to balancing the obligations of parties to an agreement.

2812 M.\&W. 67, 152 Eng. Rep. 1114 (Ex. 1843).

29 Id. at 88, 152 Eng. Rep. at 1122. 
The careful reader will suggest that Baron Parke's confusion does not concern the source of duty but stems from his lumping together leases for dwellings with all leases of real property, and his unwillingness to admit that there are significant differences between the two which would warrant a different treatment so far as implied covenants are concerned. But the Baron went on to state that "it is much better to leave the parties in every case to protect their interests themselves, by proper stipulations, and if they really mean a lease to be void by reason of any unfitness in the subject for the purpose intended, they should express that meaning." ${ }^{30}$ The rationale which he here suggests is that the tenant has adequate opportunity to inspect, and if he is not satisfied with what he sees or feels that added protections are necessary, then he may either look elsewhere for accommodations or provide adequate protections in the agreement.

To suggest that there would be no limits to a doctrine that recognized implied covenants in leases and that the tenant must be remitted to his contract rights is to deny the teachings of landmark decisions in the law of both landlord and tenant ${ }^{31}$ and sale of goods, ${ }^{32}$ where warranty-based relief was given for the failure to perform implied obligations arising out of the relationship. The Exchequer Court was not willing to recognize a developing source of affirmative duty, ${ }^{38}$ although some of the lawyers

's0 Ibid.

81 Smith v. Marrable, 11 M.\&W. 5, 152 Eng. Rep. 693 (Ex. 1843); Collins v. Barrow, 1 M. \& Rob. 112, 174 Eng. Rep. 38 (Ex. 1831); Salisbury v. Marshall, 4 Car. \& P. 65, 172 Eng. Rep. 609 (N.P. 1829).

82 Shepherd v. Kain, 5 B. \& Ald. 240, 106 Eng. Rep. 1180 (K.B. 1821); Brown v. Edgington, 2 Man. \& Gr. 279, 133 Eng. Rep. 751 (C.P. 1841).

83 The refusal of the court in Hart $v$. Windsor to recognize warranty as a source of protection for the leaseholder may be subject to analysis in a somewhait broader context, that of "status". versus "contract." One might argue that the court was inclined to remit the parties to whatever mutual obligations they could devise in contract, rather than to acknowledge right' in the leaseholder by virtue of a status analogous to that of a purehaser of goods. This conclusion would be based on a rationale that the general movement in the law at the time was away from status and toward contract. Cf. MAINE, ANcment LAw 163-65 (1864 ed.). But this is an overly-broad generalization that fails to acknowledge one salient fact, the lessee is a two-status party. He is the holder of an interest in real property and a purchaser as well. Purcliasers of goods in the Tate nineteenth century could rely on a fairly well developed scheme of warranty protection, a scheme which evolved in a time of rapid growtl of manufacturing and of independent systems of distribution and marketing. See Kessler, Protection of the Consumer Under Modern Sales Law, 74 Yare L.J. 262, 266-72 (1964). At the same time the economic system of laissez-faire capitalism depended on freedom of contract (and freedom to restrain contract) to stimulate risk-taking and investment. Hence a litigant, if he were a property owner, purchaser, and contracting party, might find himself confronted by more than one prevailing legal theory and be unable to avail himself of the most favorable. An illustration of this problem is a "pure" land case, Sutton v. Temple, 12 M.\&W. 52, 152 Eng. Rep. 1108 (Ex. 1843), where the tenant leased pasturage that was contaminated by an invisible but highly toxic substance. The court refused a defense of implied warranty in a suit for rent, and since ploughing the pasture would have constituted common law waste (amehorating in this case) the best the tenant could hope for would be to stick a sublessee 
were for they cited decided cases which established affirmative duties with acceptable limitations and argued that the circumstances in leases of houses were sufficiently analogous to those in the sale of goods that the court could apply the developing theories of warranty found there. ${ }^{34}$ But the court, stuck on a theory of express contract and not willing to acknowledge any other source of duty, denied relief to the tenants and overruled the cases decided to that point in time whicl implied such covenants. ${ }^{35}$

The question is whether or not this attitude has survived and has had an impact on modern transactions in landlord and tenant. Clearly it has. Although one could not call the statutes prohibiting implied covenants in conveyances of leasehold interests modern, ${ }^{36}$ they are still cited and have their origins in the "contract-only" thinking that convinced the English court that it should overrule or strictly limit its holdings in the implied covenant cases. This attitude is also the source of rulings in some state courts that if there are no words such as demise or grant in the lease, then no covenant of quiet enjoyment will be impled. ${ }^{37}$ And, finally, this attitude is the reason why most courts find that there can be no implied covenant of fitness, for that is still the acknowledged general rule. ${ }^{38}$ If concern is expressed by the court for an unwarranted expansion of the doctrine, counsel may refer to decisions which mention specific and limiting factors that work an exception to the general rule, without an attempt to formulate a new principle of law. For example, it has been held that the exception should apply only to short-term leases of premises fully furnished. ${ }^{39} \mathrm{It}$ has been suggested that knowledge of the use, ${ }^{40}$ the fact that there is a housing shortage, ${ }^{41}$ lack of opportunity to inspect, ${ }^{42}$ latency of the defect, ${ }^{43}$

with the unfit grass, although his lessee could defend a suit for rent on the basis of fraud. Caveat emptor!

It would be inaccurate to suggest that the law is moving with measured step toward either a "status" or "contract" theory of jurisprudence. Perhaps a satisfactory hypothesis would be that status, or "rights in the air," is a pervasive concept, perhaps a fundamental one, and that it is in a constant state of flux, subject to erosions and accretions by contract, legislation, and judicial decision.

34 Counsel for defendant based their arguments on the warranty theories which had been developing in the law of sales. 12 M.\&W. at $71-78,152$ Eng. Rep. at 1116-18.

35 But cf. the later decisions in Wilson v. Finch Hatton, 2 Ex. D. 336 (1877); and Collins v. Hopkins, [1923] 2 K.B. 617 , where relief was granted on a theory of breach of implied covenant.

36 E.g., Mich. Stats ANn. § 26.524 (1953); N.Y. Reat Prop. LaW § 251; Wis. Stats. ANv. § 235.02 (1957).

371 AMterican LAw of Property $\$ 3.47$ n.3 (Casner ed. 1952).

38 Id. at $\S 3.45$ n.4.

39 Ingalls v. Hobbs, 156 Mass. 348,31 N.E. 286 (1892).

40 Young v. Collett, 63 Mich. 331, 29 N.W. 850 (1886).

41 Barnet, Landlord-Tenant Laws and the Slums (undated mimeograph on file in Research Section, Urban Law Program, Umiversity of Detroit School of Law).

42 Schoshinski, supra note 13, at 521-22.

43 Ibid. 
and the like will justify finding the implied covenant of fitness. If these elements are controlling it makes little difference what the source of the duty is, for one could argue for such covenants in any lease on the basis of such factors. But by emphasizing the source of the duty the various classes of implied obligations can be increased. In addition to a duty to make the premises fit or a duty to repair, ${ }^{44}$ the landlord may become obligated to notify of a change in owners or management, or to notify of a cancellation of fire insurance or of the existence of code violations.

\section{Limitations Imposed by a Party}

Another himitation on implied covenants is one imposed by a party to the agreement; wherein he limits, by provision in the lease, his liability to those terms expressed in the agreement. Whether the courts will hold such limitations binding on the tenant is a matter for some speculation, although no one would seriously insist that such disclaimers are dispositive of the landlord's liability for warranties implied as a matter of public policy. Thus it may be argued on behalf of the tenant that the public good requires that obligations be imposed by implication on the landlord and that any atlempt to avoid them by disclaimer or limitation would be contrary to such policy. ${ }^{45} \mathrm{~A}$ second approach is to argue that provisions inserted by the landlord to limit his duties are unconscionable and therefore void. Of course, the doctrine of unconscionability lias developed in the law of sales, and has not matured to the point, even in that context, where one may anticipate a result with any great assurance. However, it is no great leap conceptually to accommodate the doctrine of unconscionability (or of overreaching in land transactions) ${ }^{46}$ to the law of landlord and tenant. If the lessee is unfamiliar with legal terminology and lacks a basic understanding of the relationship of landlord and tenant, if the disclaimer is oppressive, and if the current housing situation and the tenant's financial condition are such that he had little choice in selecting accommodations, then the disclaimer or limitation may be held to be unconscionable. ${ }^{47}$

It should be clear that as a general matter the road to implied obliga-

44 No such duty is established under the case law, but the obligation to make general repairs is imposed by statute. E.g., MIca. Stats. ANN. \& 5.2843 (1958).

45 See statements as to public policy and its effect on the validity of disclaimers in Henmingsen v. Bloomfield Motors, Inc., 32 N.J. 358, 404, 161 A.2d 69, 95 (1960).

46 Jolinston Realty \& Inv. Co. v. Grosvenor, 241 Mich. 321, 217 N.W. 20 (1928).

$47 \mathrm{~A}$ full discussion of unconscionable disclaimers as they are dealt with in the sales of goods appears in Hawkiand, A Transactionat Gumi: to the UnLForar Condmerclat CODE § 1.190304 (1964); cf. UNIFORM COMMERCIAL CODE \& 2-316, providing for disclaimer of implied warranties. 
tions is not trouble free, but in the case of residential housing, the only significant obstacle would be the court's unwillingness to recognize the relationship itself as a source of implied obligation.

\section{The Doctrine of Substantial Performance}

The charge has been made that the law of landlord and tenant is bound conceptually to the old rules of real property conveyancing. ${ }^{48}$ The courts, it is said, have failed to incorporate relevant doctrines from the law of contracts. ${ }^{49}$ But on closer examination, one finds that the courts have been solving landlord and tenant problems with contracts analyses and that the courts are not entirely to blame for the failure to apply contracts rules in dwelling leases. The real problems lie elsewhere. First, most of the appellate decisions in the area of landlord and tenant have centered about commercial leases, for they are of significantly greater length and involve more money than the standard dwelling lease. Since there is considerably more at stake for the parties, they are more willing to contest at the appellate level. In these cases; counsel have effectively argued contract doctrines. ${ }^{50}$

The other problem is that in most jurisdictions the lawyer representing the poor client finds that his man is a defendant and that he must confront the statutes establishing the right of the landlord to summarily regain possession. ${ }^{51}$ Whether the law of landlord and tenant has or has not assimilated relevant contract doctrines regarding the dependency of covenants is of little moment in the face of such a statute; whatever defenses the tenant may have by virtue of the landlord's failure to perform as promised cannot be pleaded. One can only show that the landlord has not met the requirements of the statute; if he has, the right to remain in possession is lost. ${ }^{52}$ Of course this street is one-way for the landlord, too, as he may not maintain an action for rent..$^{53}$ But that is of little consolation to the tenant when his main interest is in establishing some degree of permanency in his housing arrangements.

Although the covenants in a lease are mutual promises, it has long been the rule that "in the absence of an expression to the contrary, these

48 Levi, Focal Leverage Points in Problems Relating to Real Property, 66 CoLdM. L. REv. 275 (1966).

40 Lesar, Landlord and Tenant. Reform, 35 N.Y.UI. REv. 1279, 1281 (1960).

50 See text accompanying notes 56-69 infra.

51 E.g., Mrce. Stats. ANN. \& 27A.5634 (1962).

52 Ibid. The only issues which may be considered in such a proceeding are: (1) whether the person seeking relief is entitled to possession, (2) whether a proper written demand for possession or payment of rent was made the required length of time before the complaint was made, and (3) whether rent is overdue. McSloy v. Ryan, 27 Mich. 110, 112 (1873).

53 See, e.g., Gregor v. Old, 209 Mich. 43, 176 N.W. 580 (1920). 
mutual promises are not mutually conditional and dependent." ${ }^{254}$ This means in effect that the promises in a lease cannot also be constructive conditions precedent to the promisee's duty to perform. The failure of performance gives rise to a cause of action; ${ }^{65}$ it does not permit the other to withhold his performance as well. This principle began to erode at an early date, and in the English case of Smith v. Marrable, ${ }^{50}$ the court construed an imphed covenant of fitness as a condition precedent to the tenant's duty to remain on the premises and pay rent. Although the English court later withdrew from this posture, ${ }^{57}$ courts in the various American jurisdictions have not been hesitant to adopt that much of the doctrine that conditioned one party's performance on the other's having carried out his promise. ${ }^{58}$ In Michigan the court early decided that the covenants in a lease, whether implied ${ }^{59}$ or express, ${ }^{60}$ were mutually dependent, although it did not always analyze the problem in the contractual language of nonperformance of conditions and failure of consideration, ${ }^{\mathbf{0 1}}$ but lapsed from time to time into the language of constructive eviction. ${ }^{02}$

Not every breach of promise is a total breach, and not every failure of performance will enable the other party to withhold his performance. Only when a party has substantially performed may he call forth the performance of another. This doctrine has been applied to leases in a form adopted to the circumstances of landlord and tenant. In Walters v. Quality Biscuit Div., ${ }^{63}$ the defendant-tenant moved from the premises prior to the end of the term, but continued paying rent. Thereafter; plaintiff's grantor, who owned the adjoining building and through whose premises

54 3A Corbin, Contracts $\$ 686$, at 238 (1960).

55 1 Tiffany, Reat Property § 88, at 135 (3d ed. 1939).

5011 M.\&W. 6, 142 Eng. Rep. 693 (Ex. 1843); see Hart v. Windsor, 12 M.\&W. 67, 152 Eng. Rep. 1114 (Ex. 1843), where Rarke, B., states "I thought they [the cases supporting Smith v. Marrable] established the doctrine, not merely that there was an implied contract on the part of the lessor, that the house should be habitable, but an implied condition, that the lease should be void if it were not, and the tenant chose to quit." Id. at 87,142 Eng. Rep. at 1122.

57 Hart v. Windsor, supra note 56.

58 E.g., Medico-Dental Bldg. Co. v. Horton \& Converse, 21 Cal. 2d 411, 132 P.2d 457 (1942); 6 WIILTSToN, Contracts $\$ 890$ (3d ed. 1962) and cases cited therein.

59 Tyler v. Disbrow, 40 Mich. 415, 417 (1878): "[T] his consideration having failed, the lessee was justified in leaving, and in refusing to pay further rent."

${ }^{60}$ Stifter v. Hartman, 225 Mich. 101, 195 N.W. 673 (1923) (plaintiff failed to pay one-half expenses of phone and secretary, therefore defendant was justified in leaving slared premises).

61 E.g., Bostwick v. Losey, 67 Mich. 554, 558, 35 N.W. 246, 248 (1887) (plainitiff refused or neglected to repair fiume and foundations of mill, and court held the consideration failed).

62 See, e.g., Lynder v. S. S. Kresge Co., 329 Mich. 359, 45 N.W.2d 319 (1951), where plaintiff did not block off entrance to leased store as promised, and court lield defendant had been constructively evicted.

63336 Mich. 214, 57 N.W.2d 503 (1953). 
defendant's water pipes passed, shut off the flow. Defendant claimed constructive eviction and stopped paying rent. Plaintiff had a judgment for rent below, and on appeal the court affirmed, stating that "it is not every partial failure to comply with the terms of a contract by a party which will entitle the other party to abandon the contract at once."

The breach was not intentional, and plaintiff made an immediate attempt to remedy the defect. He had, in effect, substantially performed his covenants, and the breach gave the defendant no more than a right of action for damages.

What is most significant in the opinion is the suggestion that substantial performance is measured in terms of the impairment of the beneficial use and enjoyment of the premises. ${ }^{65}$ It would seem that where the use and occupation of the premises is the essence of the contract of leasing, if the failure of the landlord to meet his promised performance interferes with the tenant's use and enjoyment, and if the tenant can no longer use the premises for the activities in which he was engaged or about to engage at the time of the interference, then he may withhold his performance, treat the contract as no longer in effect, and declare his interest in the premises terminated. ${ }^{66}$ His alternative, unless there is such an interference with the possessory interest as to amount to a repudiation, ${ }^{67}$ is to treat the interference as a partial breach; sue, and tender performance. ${ }^{68}$ The fact of the underlying conveyance may affect the contract rule, however, and it may be that even in the case of a total repudiation a suit to enjoin interference may be maintained if the tenant elects to treat the lease as remaining in force. ${ }^{69}$

\section{Impact of the Summary Possession Statutes}

In light of the statutes granting the landlord a right to summary possession, speculations about the tenant's alternatives in the event of the

64 Id. at 220,57 N.W.2d at 506, quoting from Rosenthal v. Triangle Dev. Co., 261 Mich. 462, 246 N.W. 182 (1933).

05 "Neither may it be said that defendant was deprived, because of the shutting off of the water service, of any beneficial use that was enjoyed at the time, or of which it was in position to avail itself ...." Id. at 220,57 N.W.2d at 506 .

86 The common law suspended the obligation to pay rent when the tenant was evicted, but the tenancy remained in force. 1 TtFfany, Real Property $\$ 146$ (3d ed. 1939). Hence to terminate the tenancy the lessee would have to rely on some theory of surrender by operation of law, see, e.g., Hotel Marian Co. v. Walter Root, 77 Ore. 426, 150 Pac. 865 (1915), although periodic tenancies may not be subject to such surrender, 1 TrFFANY, op. cit. supra $\$ 172$, at 274 .

074 Corbin, Contracts $\$ 946$, at $811-12$ (1951).

88 Ibid.

69 See Grinnell Bros. v. Asiuliewicz, 241 Mich. 186, 216 N.W. 388 (1927), where landlord leased adjoining floor space to a meat market, and plaintiff music dealer sued to enjoin defendant's action. The court indicated it would have permitted vacation, but granted an injunction. 
landlord's breach may be wholly academic. If the tenant withholds his rent payments or if he brings a suit to enjoin an interference with his possessory interest, he may be faced with a notice to vacate and a suit to regain possession.

In the case where the landlord's failure to perform meets the requirements for a constructive eviction, it would seem unfair to permit the landlord to sue to regain possession when the tenant subsequently withholds his rent. Where the landlord by his own acts has provoked the tenant into withholding rent, although the cases and statutes do not countenance the practice, the Detroit court hearing summary actions ${ }^{70}$ will permit the tenant to show that the landlord has failed in his duty to maintain the premises, and if the tenant agrees to pay his rent within a certain time, the court will not always grant all order to dispossess. ${ }^{71}$ This is an empty gesture for two reasons. First, the court has no power to issue an order to the landlord to remedy the defect, and second, the landlord need only wait until the beginning of the next period to give notice to terminate the tenancy.

There is one Michigan case to support the tenant's claim that the landlord cannot maintain a suit for possession where the landlord himself is at fault. In Ravet v. Garelick,,$^{72}$ the court held that in the case of a partial eviction, an action under the statute for summary possession would not he, since in that instance the whole of the rent is suspended, and there can be no action for nonpayment of rent where no rent is due.

When, to punish the tenant, the landlord gives notice to terminate the tenancy; the problem is more difficult. Although various grounds have been suggested for defending against a retaliatory eviction, ${ }^{73}$ the problem of proving that notice has been given in retaliation would appear to be insurmountable once the landlord learns to give it without commenting on the reason.

The appropriate move would be to urge the legislature to amend the statute granting the right to summary possession, modifying it so that certain defenses may be pleaded. The statute should permit termination only for specific, extraordinary reasons, ${ }^{74}$ and the plaintiff should be required to plead these as an element of his cause of action. In this way the impact of the statute would be lessened, and the tenant could have some assurance of permanency, conditioned on the performance of his obhigations.

70 Circuit Court Commissioners Court.

71 Interview with Circuit Court Commissioner.

72221 Mich. 70, 190 N.W. 637 (1922).

${ }^{73}$ Schoshinski, Remedies of the Indigent Tenant: Proposal For Change, 54 GEo. L.J. 519,541 (1965).

74 See text following note 102 infra. 


\section{II}

\section{THE STATUTORY IEASE}

\section{A. Generally}

One may speculate hopefully that the courts will adopt a sympathetic and helpful attitude toward the problems of the urban poor, accepting the theories and concepts urged upon them by counsel. The problems of poor tenants have heretofore been raised in himited circumstances, generally the prosecution of actions to regain possession from the tenant for nonpayment of rent or because of an unpermitted holding over, actions where the tenant is forever a defendant.

But one must be realistic and recognize that litigation is a slow method of effecting changes in the law, even when the need is urgent and the means are at hand. And of course the major stumbling block, the landlord's statutory right to summarily regain possession, effectively defeats the tenant's interest in maintaining a permanent home. That is perhaps his most important interest, for if the tenant must leave the premises either because of a judgment of eviction or as a part of his remedy of constructive eviction, any judgment for damages which he is fortunate enouglı to win is small consolation. Hence it may be necessary to turn to the legislature for adequate protections.

The perspective of a statute can be conceived in any number of ways. An attempt to redefine the landlord and tenant relationship, setting out the tenant's minimum estate, defining the riglits and duties of the parties, and establisling conditions of performance, as in a restatement, ${ }^{75}$ would be one possible, if monumental, approach.

Another approach would be to meet selected problems on a piecemeal basis, for example, by permitting rent withholding, ${ }^{76}$ or by enacting a lienrepair law. ${ }^{77}$ Yet another method would be to establish an administrative board, empowered to control the troublesome and oppressive private housing market. But an approach that deals with problems seriatim will forever be leaving something undone, and to depend on an unwieldy bureaucracy encumbered by the usual procedural red tape will merely add to the law's delay.

A more satisfactory legislative approach would be to set out, in a statute, a uniform standard dwelling lease, binding on the parties, which balances the rights of the parties and defines the tenant's possessory interest $\mathrm{m}$ terms of a mimimum leaseliold estate.

To affirm that the tenant holds an estate, as if the transaction were

75 For a muted call for such a restatement, see 3A CorbIN, ConTracts 238 n.58 (1960).

76 E.g., N.Y. Real Prop. Actions \& Proc. LAW \$§ 769-82.

77 E.g., N.Y. MULTIPLE DWeLtTNG LAW $\$ 309$. 
one involving real property rather than rooms in a building, is a move away from what has been described as judicial recognition that a lease is no more than a promise of continuing permission to occupy the premises. ${ }^{78}$ This is a reasonable extension of the doctrine of estates, for that doctrine has been held to apply to things other than land, ${ }^{70}$ particularly where the subject matter has a relatively permanent existence. ${ }^{80}$ Clearly the fee estate has been extended to units within a building, ${ }^{81}$ and there is no reason why the leasehold cannot be sinilarly extended. ${ }^{82}$

The leasehold estate entails two characteristics that can be beneficial to the tenant. First, the leasehold is a possessory interest, that is, it carries the right to exclusive use and occupation. ${ }^{83}$ Hence, the lessee has the right to maintain possession against the owner of the fee and third parties and to sue to restrain interferences with that possession. Second, time is a factor that measures the tenant's interest, ${ }^{84}$ and since duration is a matter that may be fixed by consent of the parties, theoretically the tenant might agree with his landlord to extend the term, thereby assuring a greater degree of permanency.

The rub, of course, is that even if it is theoretically possible for the leaseholder to increase the incidents of his estate by contract, as a practical matter the landlord by contract can and does reduce those incidents so that the lessee has no more than a promise of a very limited right to occupy the rooms he rents. Hence an objective of the statute is to restore the estate concept by affirming a possessory interest in the tenant, and setting a minimum term. By setting out the landlord's obligations to protect the quality of the tenant's property interest and by prohibiting further agreements in derogation of that interest, it will be protected from erosion.

The landlord's interest, which can best be characterized as his investment or "endowment," must also be protected. Thus the contract aspects of the statute establish the parties' interests and their respective obligations in regard to those interests.

A significant problem is that of deciding which terms are important enougl to be controlled by the statutory form. For the sake of simplicity the statute should be short. But a failure to include a troublesome term

786 Winliston, Contracts 585 (3d ed. 1962).

70 Regarding future estates in chattels, see Snars, Future InTerests 18-20 (1950).

80 Cf. Cribbet, Princtples of Property 25-26 (1962).

81 This is accomplished by the statutes which create horizontal real property regimes or condominia. E.g., CaL. CTv. Code $\$ \S 1350-59$; IND. Stats. ANN. \$§ 56-1201 to 56-1231 (Burns Supp. 1965); FıA. Stats. ANv. §§ 711.01-.23 (1963) ; MTcE. Stats. ANN. \$§ 26.50(1)(30) (Supp. 1963).

82 Cf. Shawmut Nat'l Bank v. City of Boston, 118 Mass. 125 (1875), which holds that a lease is not a conveyance of real property.

831 amertcan Law of Property $\$ 3.38$ (Casner ed. 1952).

84 CrIBBEx, op. cit. supra note 80 , at 23. 
might leave the tenant at a serious disadvantage. For example, if it were concluded that the matter of a security deposit were to be left to the parties' discretion, it would be possible for the landlord to require a forfeitable security deposit that would be in excess of the rent due for the statutory minimum term. The landlord would thereby gain a distinct advantage, holding a sum which he could declare forfeit; should he desire leverage in future disputes with his tenant. Obviously, however, the statute cannot be so long and involved that it determines the outcome in every possible situation, but it must be framed to include certain essential provisions, leaving formation of the remainder of the agreement to the parties and to the existing law.

It would also be necessary, as a prehminary matter, to relate the subject matter of the proposed bill to existing statutes. In response to pressure to change anachronistic common law rules, many states have modified by statute the doctrine of estates ${ }^{85}$ and the rules of conveyancing, ${ }^{86}$ and have redefined the liability of the tenant for rent when the buildings become untenantable ${ }^{87}$ and the right of the landlord to maintain a suit for rent. ${ }^{88}$ And they have of course established summary proceedings to recover possession. ${ }^{80}$ The development of a statutory lease would require close attention to these acts to maintain uniformity of terminology and to avoid the creation of conflicts in the law.

The statute could not consist only of a standard form lease. A number of collateral matters would have to find expression, including such things as a defimition of terminology and of the minimum estate; a himitation of the statute to the dwelling lease; an explanation of the lessor-lessee relationship to distinguish it from similar relationships to which the law has attached different consequences; and a determination of the ways in which the relationship can be created, extended, and terminated. Although the following paragraphs are not actual drafts of the sections of the proposed statute, they indicate what should be contained therem, accompanied by a brief discussion of some of the problems that may be encountered.

\section{B. Provisions of the Lease}

\section{Purpose and Effect}

Most statutes do not begin with a section devoted to purpose and 'effect, but in the case of model acts, or statutes which are innovative and intended to accomplish changes in existing law, such clauses are inserted

85 E.g., Mich. Stats. ANN. $\$ \$ 26.1-.50$ (Supp. 1963).

88 E.g., MICH. StaTs. ANN. \$§ 26.521-.564 (Supp. 1963).

87 E.g., MICH. Stats. ANN. § 26.1121 (1953).

88 E.g., Mich. STATS. ANN. \& 26.1101 (1953).

80 E.g., MICH. STATS. ANN. § 27 A.5634 (1962). 
to indicate the reasons for which the statute was enacted and to encourage the courts to interpret liberally its provisions to effectuate the stated purposes. The purpose of the proposed act is two-fold: to recognize the estate interests of both parties, giving them adequate protection, and to achieve a fair and equitable balance between the rights and obligations of the lessor and lessee. It should also be stated in this section that the statute is limited in its application to leases of dwellings.

\section{Definitions}

A section setting forth definitions of the terminology used in the statute is standard where the subject matter and terminology are new, or where terms with common meanings are used in limited and specific senses, or where specific changes are being wrought. A reason for clarifying terms is to avoid confusion when the parties use statutory terms where they truly intend other consequences, such as the formation of a rooming agreement or a contract for hotel accommodations.

\section{Defining The Tenant's Estate}

The tenant's estate, in order to be recognized as a true leasehold, must have two characteristics. It inust carry the right to exclusive use and occupation, that is, it inust be possessory ${ }^{90}$ and it must have duration. ${ }^{01}$ The time dimension is presently determined by the parties, or by the law according to the way in which rent is paid. Since the parties rarely discuss the term, the tenancy is almost always periodic, week-to-week or monthly. This arrangement is hardly permanent, and the statute should recognize a minimum initial tern of sufficient duration so that the tenant enjoys some degree of permanency. One method is to bind both parties to a minimum initial term of four to six months duration, giving neither the right to terminate except for extraordinary reasons. Under these circumstances the tenant will have a greater liability than he now has, for he will be bound to pay for the full statutory period, although actual tender be in installments at thirty-day intervals. The hardship may not be too great, for the landlord and tenant will always be able to agree to a surrender. The landlord may be willing to consent to a surrender to free his premises for a tenant who can pay. The real problems lie with the poor tenant who has no money, but whose landlord would rather sue than seek another tenant, and with the individual newly arrived in the community who wants to rent for a period shorter than the minimum term before settling permanently elsewhere. To meet these objections, an alternative solution to binding both parties to a minimum term would be to

00 See text accompanying note 83 supra.

91 See text accompanying note 84 supra. 
require the landlord to recognize a lengthy minimum term, yet permit the tenant to terminate as under the present law. In either case the estate concept has been preserved, but the character of the tenancy in terms of duration will be modified.

\section{Defining the Lease}

The theory is that whenever the transaction is a lease, the interest which the tenant receives will be denominated a leasehold estate as that estate is conceived by the statute. The question is, when can it be said that the transaction is a lease? Here again, the problem of statutory definition becomes acute. Since the need is for an objective standard, an appropriate place to search for it is in other statutes with standards analogous to the one required. A statute which comes immediately to mind is the housing code. In Michigan, a proposed housing $\operatorname{code}^{22}$ provides a standard for defining the subject matter of the transaction such that every transaction involving the particular subject matter may be called a lease without doing an injustice to the actual intentions of the majority of landlords and tenants. The proposed code defines two kinds of housing units, dwelling units and rooming units, each of which has different characteristics, and each of which is treated differently under the statute. The dwelling unit is defined as one having sleeping, cooking, living; and sanitary facilities all within the unit. ${ }^{93}$ Rooming units, on the other hand, have only sleeping and living facilities, with other facilities elsewhere in the structure or absent altogether. ${ }^{94}$ If these standards are adopted, where a dwelling unit is hired for a term or from period to period and where the period is for a week or more, the law will presume that the transaction is a lease and therefore that the tenant has a leasehold estate in the premises. To establish the interest protected by the statute in this way has one adverse effect. A rooming unit cannot be the subject matter of a statutory lease, although at common law a room could be a proper subject for a lease. Of course, the roomer is clearly within his rights to bargain for a common law lease of the room, since the statute creates a lease only where the subject matter of the transaction is the dwelling unit.

If the bargaining method proves unsatisfactory for the impoverished person who wants the protections of the statute but cannot afford a "dwelling unit," the statute might be drawn so as to give any person the

92 Mich. H. 2363, 73d Leg., Ist Sess. (1965).

${ }^{83} I d$. at $\S 25(1)$. Some hotel suites would be included in this definition, and it would be necessary to qualify the definition of dwelling unit by adding the phrase "not including such units as are offered in the ordinary course of business by hotels, motels, and similar businesses serving transient chentele."

94 Id. at $\$ 60(3)$. 
right to elect the statute when he takes a rooming unit. Of course, the landlord would almost certainly reciprocate by raising the rent.

It is felt that no great injustice would be done by excluding rooming agreements from the scope of the statute, for they are the least permanent of all interests in residential housing at the common law, and to give such interests greater effect than that which they enjoyed at the common law might work a hardship on the owner of the premises and the roomer. This decision will protect transients and the businesses that cater to them from having to cope with a statute that offers unneeded protections.

\section{Creation by the Parties: Statute of Frauds}

If the agreement is oral or written, or if the tenant takes possession with the landlord's permission, the transaction should be subsumed under the statute, regardless of the nature of the tenancy which the parties intend to create. For example; the landlord may try to circumvent the statute by creating an oral lease for a term of a year or more. The lease would be void under the Statute of Frauds, and when the tenant took possession under the void lease, he would become a tenant at will ${ }^{15}$ or from period to period. ${ }^{96}$ Here the statute would apply to the tenancy created by operation of law and give the lessee a "term" for the minimum statutory period. The objective of the statute is to noodify the law of landlord and tenant and recognize a uniform tenancy with minimum standards. Any transaction which creates a tenancy whose incidents exceed those established by the statute would not be caught by it.

So long as the premises come within the purview of the statute, and so long as rent, as defined by the statute, is paid or promised, the transaction will be denominated a lease.

The need for a payment or exchange of some kind, whether or not the parties call it rent, is necessary to bring the statute into operation. A basic, agreed exchange must take place. But as soon as there is consideration moving in both directions a condition precedent to the arising of the statutory lease has been fulfilled. A gift transaction would not suffice to bring the statute into play.

The statutory form must enable parties who wish to commit their agreements to writing to comply with the requirements of the Statute of Frauds. Few poor tenants will ever lease for: a term of years; but since the statute will apply to all transactions, whether oral or written, where a dwelling is the subject nuatter, and since some persons lease apartments and houses for periods longer than a year, the statutory form must pro-

05 BURBY, ReAi PROPERTy 125-27 (3d ed. 1965).

06 See Mich. Stats. ANw. \& 26.1104 (1953); Barlum v. Berger, 125 Mich. 504, 84 N.W. 1070 (1901). 
,vide for compliance with the requirements of the Statute of Frauds. Meeting the Statute is stressed because the statutory lease is not itself a writing. The terms required by the Statute. of Frauds are not supplied by the covenants in the form, but must be supplied by the parties by "filling in the blanks." Hence, space must be provided for sucli matters as the date, a description of the premises, the rent to be paid, and the names of the parties. And of course both parties should sign. One may hope that when the existence of a statutory form is known to them, indigents will be encouraged to demand a written lease, a move that will be beneficial should there ever be litigation in regard to "filled in" terms in the lease. Whether a writing will perform any educational service in teaching the tenant something about his rights in the transaction is questionable. The only real benefits may accrue when the tenant seeks out a lawyer to engage the landlord in court.

\section{Terms Affecting the Parties' Performance}

(a) Covenants. - The draftsman should set out in detail the promised performances, keeping in mind the statutory objective of securing the parties' "property" interests. The tenant's promise to pay rent and to maintain the premises in the condition in which he received them are the covenants of greatest importance to the landlord. The tenant should have the obligation to make tenantable repairs and those repairs made necessary by his own neglect. ${ }^{97}$ On notice from the tenant the landlord slould have the obligation to make all major repairs; fully and promptly. Sucli duties as are imposed on the landlord by the housing code, so long as they affect the nature and quality of the tenant's possessory interest, should be incorporated in the lease. It should also be the landlord's duty to put the premises in fit condition for occupancy at the commencement of the term, and his covenant to that effect should be set forth. Equally important is an express covenant of quiet enjoyment, for it offers wide protection against interference with the lessee's interest.

(b) Mechanics of Performance and Remedies.-One of the major problems in the mechanics of operation under a lease is that performances of the parties have not traditionally been conditioned one on the other. This is the claim and, although the cases demonstrate that this has not been the law in every instance for many years, ${ }^{88}$ the problem still arises. Hence some provision in the lease should spell out, expressly, how the

07 This requirement suggests the tenant's common law duty to repair, which is not an oppressive burden. See 1 AnIERican Law of Property \$ 3.78, at 347 (Casner ed, 1952).

88 See, e.g., Medico-Dental Bldg. Co. v. Horton \& Converse, 21 Cal. 2d 411, 132 P.2d 457 (1942); Walters v. Quality Biscuit Div., 336 Mich. 214, 57 N.W.2d 503 (1953); 6 WIIIISTON, CoNTracts $\$ 890$ (3d ed. 1962), and cases cited therein. 
parties' performances are to be ordered. This may be done in the provision that establishes the duty or in a separate section that speaks to nothing but the mechanics of performance. Thus the problem of constructive conditions is avoided.

- Establishing the order of performance and rights to withhold performance is no mean task, for although the performances of the two parties are presumably equal in value, the landlord, in effect, "does" more than the tenant in terms of the quantum of performance. Then, too; once the conveyance is made, a substantial part of the landlord's promised performance is executed. Although one may feel compelled to permit the tenant to withhold rent when the landlord fails in his promised performance, it may not be entirely fair to landlords as a class to do so, since the statute will apply to all dwelling leases, and not just those of slum property.

Since rent withholding or any other response will be conditioned on a failure of performance, the lease should spell out what will constitute substantial or less than substantial performance. And since the failure of a condition will in most instances be a failure of consideration, the response will be a remedy and should be set forth in that section.

The statutory lease is a contract, and those remedies with which the statutory lease is concerned are for breach of contract. Hence the statute will concern itself with such things as the right to withhold rent as an alternative remedy when there has been a failure of substantial performance, ${ }^{99}$ payment of rent into escrow as a modified tender to keep the contract alive when the landlord has beached, ${ }^{100}$ suits for damages for partial failure of consideration, and the like. Since the purpose of the contract is only to protect the underlying conveyance and the property interests created thereby, the remedies which accrue to a party by virtue of his status as the owner of an estate (for example, the right of a lessee to sue to enjoin an interference with quiet enjoyment) ${ }^{101}$ are left unaltered by the statute and need not be mentioned by it.

It is of vital concern, however, to create a right in either party to terminate the mimmun statutory term under certain circumstances. The landlord should not be forced to endure a tenant who will utterly destroy the premises; and by the same token the tenant should not be forced to

99 In the absence of a statute rent withholding will generally result in eviction. For an examination of rent withholding as a viable remedy, see Comment, Rent Withliolding and the Improvement of Substandard Housing, 53 CaLIF. L. Rev. 304 (1965).

100 For the requirements of tender when the promised performance is a money payment, see 5 Corbin, Contracts $\$ 1235$ (1964 ed.). If a tender by payment into escrow is determined to be conditional, and therefore invalid, the statute would have to legitimize that arrangement.

101 Grinnell Bros. v. Asiulewicz, 241 Mich. 186, 216 N.W. 388 (1927). 
remain on the premises in the face of the landlord's manifest intent to make his stay as unpleasant as possible. For extraordinary reasons, then, the mimimum term should be terminable by either party. When the tenant is committing waste or is creating a nuisance or other disturbance that could result in a claim of constructive eviction by other tenants, the landlord should have the right to regain possession. The matter of unpaid rent during the minimum term raises a more difficult problem. A failure to meet the requirement of timely payment of rent for one month, since it is actually an installment, may not be a total breach, although a continued failure to pay would be. The solution may he in granting the landlord the right to begin an action for possession, and if the rent is tendered at trial, the relationship would remain in force. ${ }^{102}$

The tenant should clearly have the right to terminate for a substantial and continuing interference with his possessory interest. Both parties' remedies for breach of contract during the mininium term would be the same as under the general reniedies section.

If such changes in the relationship are contemplated, the summary possession statute will have to be revised to correspond with the remedies section of the lease. For the statutory minimum term no such action should lie, except for the extraordinary reasons set forth in the lease. Once the minimum statutory period has ended, the landlord would no longer exercise the same free-wheeling right to regain possession which the statute now grants. A suit for possession based on nonpayment of rent could be met with the defense of substantial failure of consideration. A suit for possession based on termination could be defended on the basis of a failure to plead an extraordinary reason. In effect, the tenant would enjoy a term of unlimited duration, so long as he paid his rent and threatened no injury to the landlord's investment. But the tenant should not be bound to stay on the premises if he has a chance to iniprove his lot, and as to him the right to terminate on thirty days' notice should remain.

One anticipated difficulty is the matter of increased costs and the landlord's attempt to compensate for such increases by raising the rent. If the landlord is not permitted to terminate the tenancy after the expiration of the minimum initial term except for extraordinary reasons, the problein of controlling his conduct in the matter of rent increases becomes acute. Shorn of legal remedies to regain possession, the landlord will surely resort to economic pressures. Rather than broach the subject of price controls in the statute, it may be sufficient to permit the tenant to contest rent increases on the basis that they were made for a reason

102 When rent is tendered and accepted in court the landlord's right to regain possession is not altered. Chiera v. McDonald, 121 Mich. 54, 79 N.W. 908 (1899). 
other than the increased cost of doing business. The tenant need show. only that the increase followed a complaint to the landlord or public authority about facilities; a suit against the landlord, participation in a tenant's council, the birth of a child to the tenant, and similar occurrences. If the statute provides that proof of such facts amounts to a prima facie case, the burden of going forward shifts to the landlord, and the tenant's battle is partly won.

\section{CONCLUSION}

The law of landlord and tenant is not so lacking in conceptual development that the indigent tenant must necessarily be denied redress in court. The heart of the matter is not entirely the shortcomings of the substantive law, rather it is a combination of related problems: the procedural anomaly of a statute which grants the right to regain possession but excludes otherwise acceptable defenses, the lack of tenant-plaintiffs and counsel to represent them, and hard-headed or recalcitrant judges whose sympathies lie with the landlords upon whom the poor descend to run their buildings into slums.

Current attempts to achieve satisfaction in the courts are meeting with some success, but success at the bar should be supplemented by a progran of progressive legislation designed to overcome many of the seemingly insurmountable problems such as too-short duration and discrimination in tenant selection based on race and economic status. The suggested legislative approach of creating a uniform statutory lease proceeds on the theory that the legal incidents of leaseholding would be of benefit to indigent persons. It is acknowledged that these incidents may be reduced by contract when bargaining is free in the market. But contract can be used to secure these incidents, and protect the landlord's investment as well, for the statute requires that the parties accept the contract, regardless of bargaining strength. The draftsmen must be farsighted, however, for whatever changes are contemplated in the law to benefit the poor will have an effect on the entire law of landlord and tenant.

The odds against the legislature giving life to a statutory lease are high. There is an element of bargaining in legislative councils that makes all other bargaining pale by comparison, and if such a statute were introduced the superior lobbying strength of the real estate interests could well outstrip that of the organized poor. In the end the statute might reflect only the needs of property owners. But the uniform lease does provide protections for the landlord's interest, in fact, it balances protections for both parties' interests, and this may be enough to ensure passage in relatively unaltered form.

Should a wide ranging effort fail, one can adopt a piecemeal approach. 
This method seems to be favored by legislators; since the smaller the steps by which one proceeds the fewer persons will take notice and complain. A legislative program, plus renewed efforts in the courts, should make an appreciable difference in the landlord-tenant relationships of the urban poor. 